\title{
TELLING STORIES: THE MYCENAEAN ORIGINS OF THE PHILISTINES
}

\begin{abstract}
Summary. The story of the Philistines as Mycenaean or Aegean migrants, refugees who fled the Aegean after the collapse of the palace societies c. 1200 $B C$, bringing an Aegean culture and practices to the Eastern Mediterranean, is well known. Accepted as essentially true by some, yet rejected as little more than a modern myth by others, the migration narrative retains a central place in the archaeology and historiography of the Eastern Mediterranean in the Late Bronze Age/Early Iron Age (LBA/EIA). In recent years, and despite an increasingly shaky theoretical basis, the migration hypothesis has nevertheless seemed to drown out other interpretations and characterizations of the period, claiming a normative position that is undeserved. In this paper I explore the continuing power of this nineteenth century narrative and seek to show why it is less convincing than its prominent status would suggest.
\end{abstract}

\section{INTRODUCTION}

Dalglish (2005, 148-9) has defined historical myths as "narratives which have a basis in history, but which have been embellished and over-emphasised to the extent that they reduce history to a limited series of caricatures and stereotypes'. One such enduring myth is that of an 'Aegean', usually meaning 'Mycenaean', migration to Canaan at the end of the Late Bronze Age/Early Iron Age c.1200 BC, which serves for many as an explanation of the origin of the Philistines (Dothan 1982; Dothan and Dothan 1992; Stager 1995). This is part of the larger story of a supposed migration of the 'Sea Peoples'. As Stone wrote, 'the origins of the Sea Peoples' culture lie in Mycenaean Greece' (Stone 1995, 13). Although a number of other researchers have expressed scepticism about the Sea Peoples story and the Mycenaean origins of the Philistines (e.g. Bachhuber 2012; Dickinson 2006, 62-7; Drews 1993; 2000; Knapp 2008; 2009; Middleton 2010, 44-5, 68-92; Sherratt 1998; 2003; Silberman 1998; Vanschoonwinkel 1999), these persist both as a general interpretive framework for understanding the period after c.1200 and as a purported narrative historical fact.

Colourful stories of the Sea Peoples as 'marauding fleets and armies of hungry displaced people' set in motion by collapse/environmental change/other migratory peoples are not hard to find in popular literature (Fagan 2004, 186; Marshall 2012). But in the scholarly literature too, for example, Fantalkin $(2006,205)$ noted that the Philistines were 'Greeks' that went too far 
away from 'their mother country'. They were completely assimilated and lost 'their ethnic and cultural identity altogether ...' because they 'penetrated too deeply into the Levant'. Ben-Shlomo $(2010,25)$ dismissed rather than discussed non-migrationist views of the origins of Philistine culture; he believes that 'the archaeological evidence continues to support the migration theory'. In a series of papers, and an important recent book-length treatment, Yasur-Landau $(2010,342)$ makes the case for a multi-generational migration from the Aegean, mostly of common people - farmers, whilst he also identifies continuities from life in the Aegean, even proposing that 'Aegean aristocratic lineages continued for centuries after the migration' at Ekron/Tel Miqne. In a recent article for this journal too, Faust and Lev-Tov (2011) also assumed the Philistines to be arrivals from the Aegean, who maintained a distinct identity in their new environment by the continued symbolic use of Aegean-derived material culture. Yet others attribute specific destruction events identified in the archaeological record to 'the Sea Peoples' (e.g. Kaniewski et al. 2011).

The putative Mycenaean/Aegean migration, its beginning placed, on the basis of pottery styles, in the second quarter of the twelfth century BC (Dothan and Zuckerman 2004; see also Sherratt 2006), is often seen as 'massive' and violent (Dothan 1997, 96; Mazar 2008, 93; Stager 1995). Stager (1995, 344), in an influential essay, imagined a mass migration of 'Mycenaeans' from Crete: 'boatload after boatload of Philistines, along with their families, livestock and belongings ... arrived in southern Canaan ..., , with an estimated immigrant population of 25,000. Yasur-Landau (2010, 342), building on the migrationist literature, envisions a folk migration of commoners, who travelled overland to Canaan through Anatolia. He estimates that only around half the estimated 25,000-strong population of Canaan were newly arrived migrants, based on the idea that the material cultures identified as Philistine and Canaanite represented distinct ethnic groups. Elsewhere, he favours a lower migrant estimate of only 'a few thousands', but occasionally slips back into line with the traditional narrative, describing the migration, or arrival, as 'massive' (Yasur-Landau 2010, 326, 334). Other authors have imagined more of an elite flight, presumably imagining far fewer migrants (Karageorghis 1998a; 1998b; 2000; 2001).

By occupying a privileged place in the narrative of Aegean and Levantine prehistory, and through constant reiteration and reification, the Sea Peoples story, and that of the Mycenaean origins of the Philistines, have, for some at least, 'become received wisdom, but our acceptance of them as self-evident truths', as Dalglish $(2005,149)$ states, 'discourages us from exploring the complexity and variety of life in the past'. In reality, the Sea Peoples' migration and the Mycenaean origin of the Philistines are no more than hypotheses, and are questionable ones at that. In this article then, I firstly show how weak the evidence is for a Sea Peoples migration, and expose the little-discussed issue of motivation. I then examine the material evidence, which is supposed to prove an Aegean origin for the Philistines, finding that it does no such thing.

I then offer a different framework for understanding the Late Bronze Age in the Eastern Mediterranean, one in which, rather than a cessation of international contacts, mobility of people and hybridity of culture were a norm, and where novelties in material culture - the use of 'Aegeanizing' materials, and possibly behaviours, can be viewed as expressions of and claims to multiple identities by individuals and groups in Eastern Mediterranean communities. For some, the views expressed here will not be new, and I will be preaching to the converted, but the pervasiveness of the migration narrative clearly requires that it be questioned, and other available positions be highlighted; many may be less aware that the migrationist narrative is a problematic hypothesis, a historical myth, rather than a historical truth. 


\section{QUESTIONING THE MIGRATION NARRATIVE}

Sandars $(1978,9)$ wrote that 'it was the Egyptians who invented the Peoples of the Sea', but in fact it is a modern name and they are a modern invention. The Sea Peoples were 'discovered', named, collectively and individually, and first identified with a range of peoples known from other sources, in 1855, when Emmanuelle de Rougé published his translation of the Year 8 inscription of Ramesses III from Medinet Habu, which recorded a sea and land victory over various groups of people (Peleset, Tjeker, Shekelesh, Denyen and Weshesh) (Silberman 1998, 269-70). Combining it with evidence for earlier battles fought by Merneptah, with Libyans and their allies (Meshwesh, Sharden, Lukka, Ekwesh, Teresh and Shekelesh), de Rougé constructed a story of post-Trojan war turmoil involving roving groups of 'Achaeans' (Ekwesh), 'Etruscans' (Teresh) and others, who attacked (or occasionally fought for) Egypt. De Rougé's students Chabas and Maspero later developed the idea that the reliefs actually represented a mass land and sea migration, caused by the ejection of groups from the Aegean and Anatolia, who then tried to invade and settle in Egypt, and were repulsed, with the Peleset ending up as Philistines in Canaan.

This basic story has been perpetuated ever since, like many myths, in slightly varying forms, with, for example, climate change or drought being blamed as the triggers for domino migrations. It is not too much to say that these small beginnings are the foundation of the Sea Peoples story, and that since the mid-nineteenth century, as Drews (1993, 51-3) points out, much has been 'based not on the [Medinet Habu] inscriptions themselves, but on their interpretation'. The migration narrative interpretations have had constant appeal because, while archaeology has provided enough material to outline a quasi-historical 'rise and fall' narrative for the palace cultures of Crete and mainland Greece in the Late Bronze Age, they appear to fill a narrative gap for the difficult collapse period c.1200 and after. They provide an illustrated and plausiblesounding story replete with characters and events, which dovetail chronologically and geographically with the end of the palaces in Greece and the development of proto-historical cultures in Canaan. The Sea Peoples are so useful as a device that, as Sandars $(1978,9)$ observed, 'if it were not for certain Egyptian texts of the 13th and 12th centuries BC their existence might have been guessed at, but certainly never known by that name'.

Even without the considerable problem of identifying historical 'peoples' from the lists, and associating them with definite points of origin, it must be noted from the start that we cannot take Egyptian monumental records at anything like face value, as Wilson (1956) noted decades ago (see also Knapp 2013, 448-9). It is known that at least some of the historical-looking information from Medinet Habu was copied from earlier monuments; rulership was claimed over places Egypt never ruled over (or did briefly some time earlier); the city of Carchemish appears on the list of sites supposedly destroyed by the Sea Peoples, but there is no destruction at the site that could be associated (Astour 1968; Drews 2000, 167-8; Knapp 2008, 334; Muhly 1984; Sagona and Zimansky 2009). Hattusa is, given its location, very unlikely to have been destroyed by any maritime raiders or farmers migrating by land. The narrative program and other details at Medinet Habu were intended not to record history, but rather to form and reify an ideological claim, displaying Ramesses III in the 'proper' way; the whole is an expression of ma'at. Some or all of the sea and land battle narratives, and the lists of participants, could have been compressed from a number of separate incidents, some or all of which may have happened in earlier times, or simply invented as a fitting 'realistic' testimony to Pharaoh and the might of Egypt. As Wilkinson $(2010,56)$ states, 
'the Egyptians were adept at recording things as they wished them to be seen, not as they actually were'.

Unsurprisingly, migrationists rarely question these weak foundations of the whole migration narrative, preferring to accept it generally and to debate often unverifiable details, such as the mode of the purported migrations (e.g. Barako 2003; Wachsmann 2003; Yasur-Landau 2003). However, Silberman (1998) and Drews (1993; 2000) have both shown that inherited ideas about these events and migrations cannot be divorced from their origins in the modern narratives created from the mid-nineteenth century onwards, or from the questionable interpretation of and emphasis on the limited Egyptian evidence that inspired, and is also often taken to confirm, the migration theory itself. Silberman $(1998,271)$, for example, suggests that the image of invaders and roving peoples at least partly originated in the popularity of invasion fiction, which was part of the late nineteenth century zeitgeist. Given such a revaluation of the evidence, it is easier to accept Drews' (1993, 51-3; 2000) objective claim that the Egyptian scenes do not describe a migration at all, and that the images of women and children in ox-carts from Medinet Habu need not represent such a mass migration of people from distant lands, rather than local people fleeing a Pharaonic raid.

The migration narrative also fails to give any plausible reason for a Mycenaean migration to Canaan, of elite or commoners, either by land or sea, or in one generation or several. Given that the textual (and material) evidence is taken to prove the migration happened, it may seem that no reason needs to be found. Yet it is surely unsatisfactory for archaeologists or historians to fail to seek convincing reasons to explain why, as well as how, Mycenaean Greeks really ended up in southern Canaan. Simply arguing about possible routes, as some do, is largely irrelevant if one already assumes that a migration happened.

Perhaps the most obvious and plausible-sounding motivation used for migration is the collapse of the palatial societies in Greece (Middleton 2010). It is often assumed that the circumstances of collapse, perhaps over decades, somehow caused people to flee Greece a refugee narrative governed by push factors (Harl 2011, 752; Yasur-Landau 2010, 336). Wachsmann (1998, 161) has argued that the Pylos rower tablets (PY An 610 and PY An 724) indicate that the Pylos palace was preparing for 'a mass seaborne migration' in which the palace itself, towns and countryside were abandoned in favour of colonies overseas. But despite the apparent depopulation of Messenia in the Postpalatial period, this interpretation begs many questions; on practical grounds alone any kind of 'Dunkirk' style or multi-stage evacuation can be thought extremely unlikely (Middleton 2010, 71-3; Yasur-Landau 2010, 336).

Yasur-Landau (2010) believes in a multi-generational overland migration of masses of farmers through Anatolia, in the wake of the collapsed Hittite empire, but this is perhaps even less plausible than a seaborne migration - Anatolia did not suddenly become an empty land conducive to the movement of thousands of refugees across it; it was still peopled with kingdoms and tribes. But again, why would migrant farmers not stay closer to home but keep pushing east and south, where in any case they would have to pass through Neo-Hittite and the rump Hittite kingdoms? As Popham $(1994,286)$ stated, 'if they were refugees from trouble at home, they chose unlikely havens'.

Inherently more plausible is that members of the elite might have fled trouble at home, possibly setting up refuge sites that resembled or borrowed features from palace states in Greece proper, and Karageorghis proposes a narrative of flight from Greece through the Aegean and to Cyprus (Karageorghis 1998a). Although this is plausible enough, this is very much a palacefocused approach to the interpretation of the material and political culture of the Late Bronze 
Age in the wider Aegean and Cyprus. Certainly it can be suggested that the apparently mainland features of various 'refuge' sites in the Aegean in LH IIIC can be attributed to the agency of locals seeking to construct their own partly 'palatial-looking' present, possibly as the mainland palace system itself was breaking down (Middleton 2010). But even if we accept a degree of elite flight into the Aegean and Cyprus, this does not explain why any Mycenaean lords would wish to end up in Canaan. Nor does it mean that they would be archaeologically visible if they did. During the Norman conquest of England a considerable number of English aristocrats left for Scotland, Scandinavia, Byzantium and Russia, places where they had connections or the prospect of a livelihood, but where they did not effect culture change (Jones 2010; Thompson 2003, 319-21).

To conclude, it has been widely assumed that the Egyptian evidence, for what it is, contains some kernel of narrative historical truth of a migration that can be revealed, refined or verified by archaeology. Yet as historians and archaeologists we are bound to be sceptical of such weak evidence, especially for the construction of such a grand historical narrative, but even for a more general characterization of the period. The story has become a meme, which requires an initial leap of faith. Taken as a general framework, its presence pushes interpretation of archaeological evidence towards the verification of the migration model. Even if we accept that some Mycenaean Greeks could be identified with (or were among) the peoples mentioned, no Sea Peoples or Aegean/Mycenaean migration is proved. We can see in fact that such a migration is also implausible. As Kuhrt $(1995,386)$ reminds us of the Sea Peoples and the period of the Late Bronze Age collapses: "the only sources for the role of the "sea-peoples" in the crisis [in Anatolia and the Levant] are the accounts of two Egyptian campaigns' - the rest is the product of modern interpretation and over a century of accumulated scholarship.

\section{PHYSICAL EVIDENCE}

While the basic migration narrative has grown up largely on the shaky foundation of modern interpretations of the Medinet Habu scenes since the nineteenth century, physical evidence from the Eastern Mediterranean has been seen to confirm its essence, ex post facto. With the Sea Peoples narrative working as a framework, material evidence can be fitted into it, whether or not it is 'what actually happened'. Faust and Lev-Tov (2011) identify four aspects of material culture taken to demonstrate the 'foreign origin' of the Philistine people: pottery, dietary practices, cooking techniques and a linear script. Of these, locally made pottery with some Mycenaean features has been most prominent in discussions, often taken, simplistically, as a marker of Mycenaean presence (e.g. Stager 1995).

Other categories of evidence frequently mentioned include architectural features such as hearths and 'bathtubs', compared with those of the Mycenaean Greek mainland in palatial times (before c.1200 BC). These features have also been taken to indicate locations dwelt in (sometimes temporarily) by Mycenaeans fleeing the mainland and crossing the Aegean sea en route to Cyprus and ultimately the Levant (Karageorghis 1998a; 1998b; 2000; 2001). Finally, the appearance of clay figurines, some similar to the Mycenaean tradition, has also played a role in identifying the Philistines as Mycenaean migrants (Dothan 1982; Yasur-Landau 2001). Yet, as with the textual evidence already examined, the material evidence also does not prove that any Mycenaean migration took place, or that the Philistines 'were' originally 'Mycenaean'. In this section, each category of evidence will be discussed in turn. 


\section{Pottery and nomenclature}

'Mycenaean' pottery has been found in the Levant since the late nineteenth century (van Wijngaarden 2002, 31). In 1908, Thiersch made a distinction between Mycenaean pottery proper and locally produced 'Philistine' pottery; the latter has been found at Ashdod, Tel Miqne, Ashkelon and other sites (Dothan and Zuckerman 2004; Mazar 2008, 90; Sherratt 2006, 361; van Wijngaarden 2002, 31). Faust and Lev-Tov (2011, 14-15) explain the 'standard migrationist' position that 'large quantities of the locally manufactured Mycenaean IIIC:1 pottery (also known as the Philistine Monochrome pottery) ... are usually considered as good evidence for the foreign origins of the Philistines' (also Stager 1995, 334). This type is succeeded by Philistine Bichrome pottery, which combines 'international' features (shapes and motifs) from Greece, Canaan, Cyprus and Egypt, and which marks, in Stager's opinion, a second stage of settlement, with 'Philistine acculturation involving the adaptation and absorption of many traditions to be found among the various peoples living in Canaan' (Stager 1995, 335).

Mycenaean IIIC:1b is the name traditionally given to this Philistine monochrome pottery (Sherratt 2006). This is based on Arne Furumark's typology drawn up in the 1940s, and was borrowed for Philistine pottery from its use with Cypriot material. The term has now largely been supplanted by the term Mycenaean IIIC:1 among Levantine archaeologists, though this is not used by archaeologists of Aegean prehistory for Mycenaean (mainland Greek) pottery. Stager, for example, in his influential chapter (1995), called Philistine pottery 'Myc IIIC', and also, tendentiously, 'Sea Peoples monochrome' (Stager 1995, 334). Yasur-Landau (2006) also expressed a preference for calling it LH IIIC, even though Myc IIIC and LH IIIC are terms which properly identify Mycenaean pottery from Greece and the Aegean. In another important paper Dothan and Zuckerman (2004) still support the use of the name Mycenaean IIIC:1, and reject other names on various grounds, mainly that the terms Philistine/Sea Peoples/Mycenaean Monochrome do not refer to 'Aegean' (i.e. Mycenaean) typologies, while White Painted Wheelmade III refers to Cypriot parallels but not to the supposedly 'even more important Aegean affinities' (Dothan and Zuckerman 2004, 2).

Clearly, with a migration story already in place as a narrative framework, the use of terms related properly to material from Mycenaean Greece has created and constantly reified the idea of the closeness of Greece and the Levant at the end of the Late Bronze Age and in the Early Iron Age, suggesting the movement of migrants, who reproduced their 'native' pottery overseas. This may eventually cease, as Mountjoy (2010) notes that the preferred term for Philistine Monochrome/LH IIIC: 1 is now simply Philistine 1. But this too may be problematic: even if we admit that the Peleset of the Medinet Habu reliefs indicates 'Philistines', 'the situation established in the 10th century cannot be translated back into the 12th' (Sandars 1978, 167). That is, the situation on the ground may have been much more ethnically complex than suggested by the term 'Philistine', with other 'peoples' quite possibly present and making/using the pottery; a distinct 'Philistine' identity may have 'evolved' over time (and even then may have been dynamic). In addition, Sherratt $(2005,34)$ points out that the characterization of this pottery as 'Philistine', as denoting an ethnic group, is also problematic because it is found as far north as Cilicia.

Some compromise is possible though, without being misleading. Killebrew $(1998,163$; 2005) labels the Philistine pottery as 'Aegean-inspired' pottery with 'forms and decorative motifs which appear in significant quantities throughout most of the Aegean, in Cilicia, Cyprus, and at a number of coastal sites in Syria and Palestine during the 12th century BC'. Janeway (2011, 
177) talks of 'Aegeanizing' pottery at Tell Tayinat (see also Janeway 2006-7); and Verstraete (2012) concludes that the 'Aegean' pottery in the Amuq Valley is rather 'Aegean-like' or 'local'. In the central Mediterranean, where import replacement also took place, Russell (2010) describes a type of Sardinian pottery as 'Aegean-style' or 'Aegean-looking'. These terms are helpful for making a clear distinction between Mycenaean pottery and local pottery with Mycenaean (derived) features from outside mainland Greece and the Aegean, and reduce the implication or suggestion of migration.

To return to Philistine 1, supposed to indicate arriving Mycenaeans, it is now recognized that, like Bichrome, it is not simply a locally produced Mycenaean pottery; it incorporates a range of international influences. Local (Canaanite) shapes and decorative motifs are found, as are those drawn from the eastern Aegean, Crete, Cyprus and the Levant, as well as Mycenaean tradition (Mountjoy 2010; Sandars 1978). Influence was not all west to east either; Levantine styles seem to have influenced Cypriot styles, and the herringbone tree motif found on some Philistine 1 pottery appeared in Greece in LH IIIC pottery after it appeared on Cyprus (Mountjoy 2010, 7). It also has to be considered that the Philistine pottery does not have as wide a repertoire as Mycenaean pottery, unusual if it is being made by migrant Mycenaeans (Dickinson 2006, 62). Even if pots did equal people, Philistine 1 could never simply indicate arriving 'Mycenaeans'; Sandars $(1978,167)$ explained that 'it is no good looking for a clue to the "origin of the Philistines" in the pottery. What we find is evidence for an intermingling of peoples .... Since pots do not simply represent people anyway, what we have is a hybrid style, a bricolage, which there is no compelling reason to attribute to new people, rather than to existing people actively shaping their material culture to suit their desires.

Though Dothan and Zuckerman $(2004,2)$ describe the 'most important' affinities of Philistine pottery as 'Aegean', a subjective view, it may well reflect the use and development of styles already known, and thus be a hybrid style. As van Wijngaarden (2008) reminds us, Mycenaean-type pottery had been in circulation in the Eastern Mediterranean for over two centuries, found at over one hundred sites in the Levant. Levantine people knew and had access to Mycenaean material and style. He suggests that 'Mycenaean-type pots' in the Mediterranean, in the cosmopolitan context of the times, may have served as generically 'international' rather than 'Aegean' markers for Levantine people (see also van Wijngaarden 1999).

Russell (2010), looking at what he terms 'Aegean-style' or 'Aegean-looking' pottery in Sardinia, hypothesizes that it may have been used as an exotic status marker by one nuraghe elite, but notes that this strategy ultimately failed; the material, he suggests, lost its exotic status when direct contact with traders bringing the authentic pottery into the island ended. Elsewhere, Mac Sweeney $(2009 ; 2011)$ has discussed the sophisticated and deliberate uses of 'exotic' styles in pottery picked up and rejected by the inhabitants of Beycesultan, in western Anatolia. These cases demonstrate that local people could, for their own reasons, desire and mimic exoticseeming products that would indicate something, such as a claim to a particular status, to the people around them.

It should not be forgotten that this phenomenon of adoption and adaptation is normal and is a less extreme explanation of culture change than a migration story. Mixing of styles need not be seen as mixing of distinct ethnic groups or peoples who have come together, as if a material culture was a simple representation of a primordial ethnicity. For example, Barrett (2009, 211, 226) has observed that Minoan and Minoanizing pottery in Egypt played multiple roles in identity formation and 'may have enabled Egyptians from various socioeconomic backgrounds to participate in an internationalizing cultural milieu'. Might the same not be the 
case for Canaanites and Philistine pottery? We might also recall the influence Minoan pottery had on Mycenaean LH I and LH II styles, which, like Philistine pottery in Canaan (Bunimovitz and Lederman 2011), formed a minority of early 'Mycenaean' assemblages, which remained dominated for some decades by wares derived from mainland Middle Helladic traditions (Hood 1978). Minoan LM IB pottery from Phylakopi has recently been reinterpreted as being Mycenaean LH IIA, a mainland 'pseudo-Minoan' copy of Minoan pottery, possibly, though not necessarily, made by Cretan potters (Mountjoy and Ponting 2000).

To conclude, so-called Philistine pottery cannot be accepted prima facie as evidence of a Mycenaean/Aegean migration. If anything, it indicates the selective adoption of Mycenaean styles, an exotic tradition which had already been visible in the Levant for a long time. It represents a hybrid ware that makes use of local and localized traditions, and was the product of a particular social context where there was a variety of inspirations present for potters to draw upon in ways meaningful to their customers. It also represents continued international contacts in the Eastern Mediterranean of the Postpalatial twelfth century. Bunimovitz and Lederman $(2011,44)$ even conclude that the same potters made both Philistine and Canaanite pottery. Indeed, in many places where it ended up, Mycenaean imports came to be replaced by local imitations (Mountjoy 1993, 170-5; Sherratt 1998, 302; 2001, 237; 2003, 40). Sherratt (1998, 302) notes that 'far from being taken as some kind of conscious ethnic denominator with genetic race or language embodied in the fabric - [it] can equally be seen as a continuation of the process of import substitution which saw the beginnings of such production on Cyprus in the 13th century'.

\section{Dietary practices}

Food consumption and preparation are sometimes considered to be conservative practices, and therefore to be good indicators of ethnicity - and markers of migration (Stone 1995, 18; Yasur-Landau 2010, 5). Ben-Shlomo (2011, 190) regards pork consumption as 'characteristic of Aegean sites', while Faust and Lev-Tov (2011, 15) identify it as a foreign practice 'brought by the Philistines from their place(s) of origin'. Following Stager $(1995,344)$, they too suggest that this was the Aegean, and that it was normal practice there to consume 'large quantities of pork' (Faust and Lev-Tov 2011, 20). However, it is not clear why they, or others, follow this line of reasoning because, as they themselves admit, pork was also consumed elsewhere in the regions west of the Levant.

Was eating large quantities of pork a normal 'Aegean' practice? Certainly pigs are recorded in the Linear B records, alongside goats, sheep and cattle (Palaima 2004, 222); Halstead (2003, 258) notes that 'textual and faunal deadstock records comprise a relatively balanced mixture' of these four main domesticates. The same four animals were raised on Cyprus too, but, as Steel notes (2004a, 290), the extent to which meat products were incorporated into the diet remains unclear; she suggests that goats rather than pigs were raised for meat. Using stable isotope analysis to investigate the sources of dietary protein in LBA mainland Greek populations, Petroutsa and Manolis (2010) found that most animal protein came from the milk and meat of sheep, goats and cattle, rather than pigs. They also note variation in protein sources at sites in mainland Greece, with a mainly plant-based diet likely at some sites and a higher amount of meat consumed elsewhere.

Lipovitch (2006-7) compared faunal assemblages from three LBA sites in mainland Greece with Iron Age Ekron and Tell Tayinat, and although he notes a preference for beef and 
TABLE 1

Percentage of domesticates from faunal analyses of three sites in Greece, Ekron and Tell Tayinat (Amuq Valley)

\begin{tabular}{lllr}
\hline & Beef & Sheep/goat & Pork \\
\hline Tiryns (LH III) & $58.6-75.8$ & $9.0-21.7$ & $14.3-18.3$ \\
Nichoria (LH III) & $26.6-42.8$ & $13.6-28.8$ & $23.7-36.6$ \\
Lerna VII (LH III) & 27.6 & 17.4 & 41.2 \\
Ekron (Iron 1) & 64.6 & 19.8 & 15.6 \\
Tell Tayinat (Iron 1) & 25.9 & 72.1 & 1.8 \\
\hline
\end{tabular}

(Data from Lipovitch 2006-7.)

pork, the results are varied and not open to simple interpretation as to 'normal' dietary preferences (Table 1). At Lerna VII, the sample was very small, and the high proportion of pork may indicate a sanctuary or feasting in this context as at Ayios Konstantinos, where pig remains (juveniles in particular) comprised 30.3 per cent of total faunal remains (Hamilakis and Konsolaki 2004); high proportions of cattle remains may also reflect the remains of feasting rather than normal day-to-day dietary practices (Stocker and Davis 2004). As Lipovitch (2006-7, 158) noted, the faunal records between Tell Tayinat and Ekron also differ, and this may in part be due to adaptation to the local environment. If the local environment is a factor in diet, any putative identification of animal remains with 'ethnic' dietary habits becomes less convincing.

Should we even assume that diet, or even cooking or eating techniques, are usually standard throughout an ethnic group or community? Pythagoras and his followers were vegetarian, but no less Greek, Roman gladiators and soldiers were more or less vegetarian (and of varied ethnic origins), not all Chinese eat pork, while not all Jewish people avoid it (Kleinman and Benson 2006; Longo et al. 2008). Emery (2002) has shown that access to animals and animal resources in Maya communities varied by status, and this is also well known archaeologically from Pompeii and historically from Roman literature (Beard 2008, 223). Indeed, in LBA Greece it is likely that there was different access to meat according to status in palace-sponsored feasting activities (Isaakidou et al. 2002; Stocker and Davis 2004). It is likely that as well as variation by status and environment, there were also gender-based dietary differences, as suggested in Iezzi's (2009) study of East Lokrian women; she observes that many women may have 'experienced a lifetime of nutritional deficiency, possibly related to living in a patriarchal society with unequal access to high quality foods' (188).

Communal feasting practices in LBA Greece and Canaan helped bind people together, but also, as Roman banquets did (Beard 2008, 217-18), served to create and reinforce social differences in status and position through such features as the range of food and drink consumed, the crockery and paraphernalia supplied, the use of space and time, and proximity to particular individuals, all of which could be status graded (Isaakidou et al. 2002; Stockhammer 2011; Wright 2004; Zuckerman 2007). In Mycenaean palace states, Linear B and archaeological evidence suggests that larger and smaller feasts involving different people and groups took place at different locations across the year (Palaima 2004; Stocker and Davis 2004). Diets varied across the social spectrum (in types and amounts of food, and its regularity of consumption), and the majority of people (presumably subsistence farmers) in LBA Greece may not have consumed meat (as opposed to secondary products) very often, perhaps mainly at special communal occasions of one sort or another. In fact Lis' (2006) analysis of cookware from the Pylos palace notes that 'it is . . . quite striking how little cooking equipment . . . seems to be designed for meat 
preparation' (20). The heroic slant of Homer, not in any case a clear representation of LBA or EIA life, but which may influence general views of Mycenaean diet, plays up the role of meat and feasting in everyday life as part of its portrayal of life at the top for the heroes of the past. Meat, including pork, may well have been less generally important for most people (both the 'subjects' of real LBA rulers and later listeners to the poems) than the epics themselves imply.

Diet is not a fixed or unchanging ethnic trait, and change in diet is also a matter of choice, culture and meaning (Eriksson et al. 2008; Jones et al. 2011; Norton 2006; Twiss 2012). In East African communities of the eleventh century, in contact with Indian traders, for example, a shift to an Indian rice staple may have been part of a local people's expression of cosmopolitanism - it was not a marker of ethnicity (LaViolette 2008, 38). Rice had by this time also travelled to Korea, Japan and elsewhere through ongoing contact and interaction, rather than migrations. In the Colombian exchange, crops and foodways also flowed into Europe without any significant American migration (Nunn and Qian 2010).

Considering the likelihood of status variations, and the various contexts of consumption, it is difficult to recognize and compare 'normal' meat diets from textual and faunal assemblies, and to associate them with ethnic identity or a specific point of origin. We should not assume that dietary (and other) habits do not change, especially when people are in contact and moving about, as they were throughout the LBA and EIA. Even as a new practice, pork consumption in the Levant could simply represent a change in culinary tastes or practices, an ecological adaptation, or a change in subsistence strategy. Alongside 'foreign-seeming' pottery it could represent an exotic or 'cosmopolitan' practice newly created and valued by a section of local society, or a practice associated with status or religious rather than ethnic identity, without any need to posit an influx of new people (Twiss 2012). For Faust and Lev-Tov (2011, 18), nonconsumption of pork was used by Israelites to create a point of differentiation from the porkeating foreign Philistines, as it was used to define Jews against other groups in later times (Rosenblum 2010), for whom pork consumption may not have been in itself significant (at first). At any rate, evidence from diet is no proof of a Mycenaean/Aegean migration.

\section{Cooking techniques}

Linked with dietary practices are cooking techniques. Faust and Lev-Tov $(2011,15)$ note unique Philistine techniques including the use of hearths and cooking jugs, which are traced to an Aegean origin; 'Aegean' cooking materials are found side by side with traditional Canaanite practices and materials (Yasur-Landau 2010, 227-40). Hearths are discussed below. The greater amount of Philistine cookware at sites in the 'heartland' is taken as an indicator of its ethnic significance, rather than any other social value, supposedly representing the preservation of Mycenaean or Aegean foodways by immigrants living alongside local Canaanites (Bunimovitz and Lederman 2011, 42).

Mycenaean cooking techniques included the roasting and boiling of meats (Sherratt 2004; Sherratt and Hamilakis 2012; Wright 2004). While cattle would, in feasting contexts, have been roasted over a fire, other meats seem likely to have been boiled in tripods (especially tough game meat from hunting) (Wright 2004, 161). Tripods are found in both higher and lower status sites. The short legs of cooking tripods, which provide stability, indicate that they were used over covered fires (Tournavitou 1992, 202-3). Philistine contexts reveal no tripods, only cooking jugs (Ben-Shlomo 2011, 189; Dothan and Zuckerman 2004), on which basis Yasur-Landau (2010, 329; unlike Stager 1995) rules out any migration from Crete, where tripods were used; indeed he 
regards them as a 'most indicative' type (239). But mainland Greeks also cooked in tripods, and if Mycenaean people did migrate east, and both diet and cooking techniques are inherently conservative, the absence of tripods is difficult to explain without admitting a more complex relationship between people and culture (Dickinson 2006, 63). Yasur-Landau (2010, 239) suggests a functional adaptation, but this undermines the supposed ethnic affiliation that cooking ware is used to posit in the first place.

In addition, as Rutter $(2007,295)$ has noted, there is actually variation in cooking habits between sites in LH IIIC Greece, which is demonstrated by the popularity of cooking tripods at Lefkandi but not at nearby Mitrou - both Mycenaean sites. The presence or not of certain types of pot may have little to do with ethnicity or ultimate physical origins of a person or their ancestors, as opposed to the practices, habits, and local economies and environments of particular communities.

\section{Linear script}

Faust and Lev-Tov $(2011,15)$ cursorily mention this category of evidence, and suggest that the arriving Philistines used a linear script 'different from those in Canaan, and ... which was probably based on the Aegean linear script, or at least incorporated some of its components'. The evidence from Ashkelon consists of 18 inscribed pot handles and an ostracon; five pots were from Cyprus and one from Crete, all of which were older than the remaining 12, produced in the twelfth century in the Levant (Cross and Stager 2006, 129). These apparently represent a modified form of Cypro-Minoan devised by Philistines (Cross and Stager 2006). Cypro-Minoan, in use between the sixteenth and eleventh centuries BC, possibly slightly longer (Hirschfeld 2010), is only securely attested outside Cyprus at Ugarit, where Knapp $(2008,172)$ suggests it may represent a Cypriot presence (merchants/officials), locals involved in Cyprus-related transactions, or an adoption of Cypriot culture by the Ugaritic elite; some cuneiform tablets from the king of Alashiya, found in Ugarit and Egypt, certainly originated on Cyprus (Goren et al. 2003).

The Cypro-Minoan system has affinities with Cretan Linear A, which, in early examples on clay, seems to have been impressed like cuneiform, suggesting it was devised purposefully with knowledge of multiple writing practices from elsewhere (Hirschfeld 2010). Cypriot Syllabic was more akin to Linear B, and was used from the eleventh century to Classical times to write Greek; it was used to write the Greek name 'Opheltas' on an iron spit in the eleventh century, in a practice common enough in the Near East, but very different from mainland Greek uses of Linear B (Sherratt 2003, 226-7). The origins of Cypro-Minoan and the development and use of scripts on Cyprus are complex, with both native and Aegean 'influence' (Bombardieri and Jasink 2010). So, rather than a truly Aegean linear script, which would be Linear B, used in the mainland Greek palaces, this evidence of a linear script is related, hypothetically, to Cypriot Cypro-Minoan script, used to write non-Greek language(s), appearing in a form not otherwise known.

In this case, clearly, Cypriot is not the same as 'Aegean' or 'Mycenaean', and neither Hirschfeld $(2010,379)$ nor Davis (2011) considers the claims made about this evidence to be substantiated. Pots are mobile and could be used for different purposes: to move goods and in burials; 12 jugs with inscribed handles from Enkomi have been claimed to name those interred, though the Ashkelon pots are from domestic contexts (imports or reused items?) (Cross and Stager 2006; Hirschfeld 2008, 125). Yasur-Landau (2010, 308-10) suggests the initial Aegean/ 
Philistine migrants, from a post-literate, post-Linear B Greece, were illiterate (he believes in a commoners migration), and borrowed from Canaanites and Cypriots in developing literate administrative traditions. As Sherratt (2003) suggests, literacy was probably very restricted in mainland Greece, in practitioners and purpose, but more widespread on LBA Cyprus. But in the Levant generally, and at Ashkelon, there were already literacy practices involving the use of cuneiform tablets and potmarks (e.g. from Raddana), with writing in use in thirteenth century Palestine, and there would also have been awareness of hieroglyphic and other systems used by Egyptians who had occupied Canaan (Cross 1968; Cross and Freedman 1971; Horowitz et al. 2002).

The Ashkelon evidence cannot be pressed to provide evidence for any general literacy or the presence of a literate administration, or for the presence of Mycenaean/Aegean migrants; the potmarks themselves may have been inscribed elsewhere and be meaningless in their find context. Given that we are supposed to be identifying migrants through 'alien' practices, if 'foreigners' are learning new forms in a multicultural Eastern Mediterranean milieu, how then can we decide that some aspects of material culture or practices are indicative of a particular ethnic identity or geographic origin but others are not? There is no need to suggest that the adoption, transmission or modification of scripts requires migration rather than contact and desire; Linear B is itself thought to have been adapted from Linear A, but without any 'Minoan migration' to mainland Greece.

\section{Figurines}

Figurines represent an additional category of evidence cited in support of the migration hypothesis. Ben-Shlomo and Press (2009), based on a reanalysis with additional material from Ashkelon and Ekron, identify three 'Aegean-style' figurine types: the standing psi-type, most famously the so-called Ashdoda figurines, and bovids, all of which are reckoned to represent (a continuation or development of) Aegean cult practices by immigrants (see also Ben-Shlomo 2011, 190-5).

The few animal figurines (bovids) found look similar to Late Mycenaean and Cypriot examples, but their types, numbers and distribution are very limited (comparing Ben-Shlomo and Press 2009, French 1971, pls. 24-6, and Steel 2004b, pl. 25). They do not represent the full range of Mycenaeaen zoomorphic figurines (French 1971, 151-64), and this may be significant in interpreting them. Even if brought by Mycenaeans/Aegeans or Cypriots, they would hardly indicate significant numbers of people, and their place of origin would remain unclear.

The distinctive 'Ashdodas', in the shape of a seat, are often interpreted as (mother) goddesses, and assigned an Aegean origin (Dothan and Dothan 1992, 153-6; Stager 1995, 346; Yasur-Landau 2001). Ben-Shlomo $(2011,193)$ notes that the seated goddess 'concept probably originates with Mycenaean seated female figurines'. However, it is generally admitted that these are quite different from Mycenaean figurines, and only appear later on with Philistine Bichrome; there are better parallels in form amongst Cypriot LCII figures, where chair and body are merged (Dothan and Dothan 1992, 156; Sherratt 1998, 302 n. 17; for an illustration see Vanschoonwinkel 1999, 101). Even Ben-Shlomo and Press $(2009,49)$ note that the type 'deviates from Mycenaean ... prototypes', but include it as 'Aegean' (including Cypriot). Vanschoonwinkel (1999, 90-1) notes that beyond a superficial similarity between Ashdodas and Mycenaean figurines, they also have some 'striking differences' and features of a local Canaanite origin. Ashdodas, like Philistine pottery then, are a 'new and unique' bricolage. Their development requires no 
Mycenaean migrant communities to have arrived; as stated they are more similar to Cypriot figurines. They can be regarded as a product of an international milieu. The pre-existing Canaanite figurine tradition also continues alongside the Philistine, suggesting that new 'exotica' may indicate a claim to a different identity by certain people within Canaanite communities (Ben-Shlomo and Press 2009, 40).

The psi-type figurines seem to offer better parallels with mainland LH IIIC figurines, but again the figurines are not simply 'Mycenaean' or 'Aegean'; hence they are seen as part of a process of 'creolization' resulting from migration (Ben-Shlomo and Press 2009, 40, 68). Ben-Shlomo and Press $(2009,68)$ may well be right that 'the similarities in the form of figurines found in the 12th century b.c.e. in the Aegean, Cyprus, and Philistia may reflect a significant connection between these populations during this period', but the connection does not need to be any sort of mass migration of Mycenaean Greeks.

At this point, we might remember that French $(1971,106)$ associates the increasing popularity of figurines in mainland Greece in LH IIIA with increased contacts (not migration) between Greece, Cyprus and the Levant: 'Mycenaean traders visiting this part of the Near East would have found long-established cults of female deities of the Ishtar group, in which terracotta figurines and plaques were widely used.' If mainland figurine iconography and practices were stimulated by external contacts and exposure to exotic foreign practices, should Philistine figurines (and there are only around 120 specimens compared with over 1000 from Mycenae alone (Ben-Shlomo and Press 2009, 63)) be seen simply as a result of an Aegean migration rather than some similar process of ongoing contacts in the Eastern Mediterranean?

\section{Hearths}

Dothan $(1997,102)$ notes the similarity of a monumental circular hearth $(1.2 \mathrm{~m}$ in diameter) at Ekron, with a pebble base and plastered edges, on and around which animal bones were found, to those in the palaces of Pylos, Tiryns and Mycenae, which she says 'represented a tradition that reflected the social structure and habits of everyday life in the Aegean (and Cypriot) palaces'. Mycenaean hearths, as palatial features, are circular, and argued to be connected with the rulership of the wanax (Kilian 1988a; 1988b); in the collapse c.1200 these features lose their significance in Postpalatial architectural arrangements at Tiryns and elsewhere; in LH IIIC, House P at Korakou has a rectangular hearth (Maran 2001; Middleton 2010, 88, 97-100).

The hearths at Ekron look similar to mainland Greek palatial hearths, but date initially from the twelfth century (Iron 1a), modified in the eleventh (Iron 1b), a considerable remove in time from the Mycenaean palaces (University of Minnesota n.d.). The monumental building of the twelfth century (Iron 1a) bears scant resemblance to thirteenth century palaces, bar the massive circular hearth; but this is located not in a prominent place in a throneroom, but rather is hidden from the larger part of the room in some kind of niche behind a wall (an entrance?). This seems to indicate quite a different function for the unit. In Iron 1b, the building was reconfigured, and a hearth was situated between the main room's central row of three columns and the fronting wall between two siderooms (one an altar niche).

The eleventh century building does look more like some of the modified Postpalatial buildings at Tiryns and Midea, where 'palace' buildings were redesigned to have a single row of columns, but has a two-column portico more typical of earlier buildings; again there is nothing strikingly 'Aegean' about the small hearth, next to the wall. The Philistine buildings and hearths 
are not clearly 'Aegean' and as novelties or hybrids, they need no arriving Mycenaeans/Aegeans, modified by travel through Anatolia, as Yasur-Landau (2010) argues, to build them. Indeed, why would migrant farmers reconstruct 'palatial' features? In plan, these buildings are not dissimilar to LBA architecture of the region (Fritz 1987).

Killebrew (2006-7) explains that Philistine hearths, rectangular in early stages and later circular, are new domestic features that most closely resemble Cypriot, rather than Mycenaean or Aegean, domestic hearths. She notes that the spread of hearths as architectural features which first appeared in Anatolia and later in Crete - attests to the 'complex multi-directional nature of Late Bronze Age cultural interaction' (Killebrew 2006-7, 253). Hearths were not 'possessed' by a single ethnic group in the Eastern Mediterranean BA, and their use (practical in a domestic context, symbolic and ideological in a palace megaron or ritual space) and meanings could spread, differ and change. Philistine hearths do not clearly replicate the functions of hearths in palatial Mycenaean culture, and are not indicative of the ethnic identity of their users; they are not evidence of a Mycenaean/Aegean migration.

\section{'Bathtubs' and textiles}

Some bathtubs, found in mainland palaces and elsewhere, may have had ritual or social functions related to greeting visiting guests, as is suggested in the arrival scene of Telemachos at the Palace of Nestor (Odyssey 3.464-8). This idea, even without the existence of a 'real' Homeric LBA world, has influenced the interpretation of 'bathtubs' found elsewhere in the Aegean, Cyprus and the southern Levant, thought to represent migrating Mycenaean elites (Karageorghis 1998b; 2000; Dothan 2003; Mazow 2006-7, 291-2). However, some of the 'bathtubs' are better interpreted as part of textile processing, similar objects serving a different purpose (Collard 2008; Mazow 2006-7).

Textile manufacture and dyeing may have been a key economic activity of the LBA/ EIA, albeit one less archaeologically visible than the flow of near indestructible pottery, but important in social and political relations. The Harris Papyrus 1 notes that Ramesses III, in the manner of later Roman emperors with their foederati, supplied the 'hordes' of Sea Peoples he settled (Sherden and Weshesh) with 'clothing and provisions from the treasury and granaries every year'; the Peleset were 'reduced to ashes' (Barnett 1975, 377; Killebrew 2005, 204). Guests, like Telemachos, for example, or participants in rituals may have been supplied with new clothes. At Salamis, Kanakia, a LH IIIB site continuing through into LH IIIC, the industrial use of bathtubs may already be identifiable, but the spread of bathtubs may represent the development of an industry rather than an ethnic migration (Middleton 2010, 76-7). Loomweights 'of a clear Aegean lineage' found at Philistine sites (Barako 2000, 523-4) also do not necessarily represent transposed Aegean people, but could indicate changing practices in textile manufacture. In LM III Crete, bathtubs were used for industrial purposes and for burials (Dickinson, pers. comm.).

\section{CONCLUSIONS}

Stone $(1995,13)$ observed that while 'the Mycenaean origin of any single culture trait can be questioned, the evidence, when taken as a whole, reveals a radical transformation of coastal Levantine culture from Canaanite to Aegean'. Yet while a novel material culture that we name 'Philistine' may have appeared, which took its inspiration from Cypriot versions of 
Mycenaean, and was mixed with local Canaanite culture, the implication that this was due to a migration rather than local people's agency in constructing novelties in material culture is still not proved. Philistine culture is found among Canaanite culture, and so can be thought of as part of it, rather as the Late Helladic culture of Greece, with its initial strong Minoan influences, appeared among and alongside its Middle Helladic predecessor without any necessary migration. Different aspects of 'Aegeanizing' culture in the Levant may mean different things. Some of it may be an expression of some sort of deliberate status differentiation within Canaanite communities, other aspects may simply indicate transfer of technological or religious ideas.

Having examined first the migration narrative, and then the material culture supposed to indicate a migration of Mycenaean Greeks (or 'Aegeans') to Canaan, we find the former to be based on shaky nineteenth century interpretations that underpin a modern migration tradition, and the latter to be unconvincing and exaggerated when it comes to proving a migration. Mycenaean-style pottery was locally made in many locations after c.1200 BC, and there is no pressing reason to believe that all or any of it represents actual 'Mycenaeans'. It is certainly wrong to assume the migration story to be true in essence or valid as a historical characterization of the twelfth century BC in the Eastern Mediterranean; it seems unlikely that the Philistines were migrant Mycenaeans - the Philistine material seems, in any case, closer to Cypriot rather than 'Aegean' or strictly Mycenaean culture. What the evidence does seem to indicate is continued maritime contacts between Greece, the Aegean and Cyprus to the west, and Cyprus, Cilicia and the Levant in the east, and a valuing, sharing and hybridization of selected aspects of western material culture on Cyprus and in the east.

The pervasive presence of the migration narrative increases the likelihood of accepting that the material evidence is proof that a migration of some kind happened. The material evidence then seems to prove that there is some justification in piecing together tiny fragments of textual evidence into a migration narrative. There is the risk of a circular argument here. But seen objectively, the narrative is more modern myth than history and the Philistine material evidence, while displaying Mycenaean and/or Mycenaean-derived features, is in no sense straightforwardly Mycenaean, rather than hybrid. The mixed nature of the material need not signify a mixing of primordial and distinct races or ethnic groups, who are represented by specific sets of material, since there is no simple equation of ethnicity and material culture.

To those used to working within the migrationist framework, the views represented here may seem isolated and revisionist, but in fact the burden of proof lies with those who believe in some kind of Mycenaean/Aegean migration and transformation into 'Philistines', since the material can be explained in more simple ways (albeit ways that represent complex processes and relationships, which probably remain largely unknowable). Writing of the Sea Peoples, and the Philistines in particular, Sandars $(1978,201)$ stated decades ago that 'the most controversial group of all is that of the Peleset ... who have sometimes been brought in ships from the Aegean and mainland Greece ... but who appear in fact to be more landsmen than any of the others. . . . Their cities in southern Palestine were not harbours, and there is very little to connect them with the sea at all.' Drews (1998) also argued that Peleset were local Canaanites. Others also doubt that the Philistines were Mycenaeans (Vanschoonwinkel 1999).

This brief survey suggests that no archaeological evidence, and no category of evidence, alone or in concert, is enough to prove beyond doubt that any Mycenaean or Aegean migration took place, nor that such people 'became' Philistines. Philistine material culture is clearly a bricolage that draws inspiration from a number of sources; it does not reflect in any simple way the ethnicity of its makers/users, the majority of whom seem likely to have been local. It may 
reflect changing economic and social priorities of some local people, who perhaps were opting in to an international textile industry, and adopting a novel identity based partly on locally known 'foreign' (but rather 'international') material and motifs, some of which were hybridized with local traditions. However, to disbelieve the migration narrative is not to assert that there was no movement of people - mobility was a normal feature of life in the Eastern Mediterranean. These changes happened at a time of continued mobility, contact and interaction, with a political and economic scene that could change rapidly and profoundly, with various state collapses, but also that were taking place over a long period of general transition from the world of the Late Bronze Age to that of the Early Iron Age.

\section{Acknowledgements}

I dedicate this paper to Oliver Dickinson, since it revisits topics we have often discussed; I thank him, Robert Lowe and James Whiting, and the anonymous reviewer at OJA for helpful comments on a long initial draft. I am also grateful to Naoise Mac Sweeney, Tom Tartaron and Johannes Verstraete, who kindly sent me copies of their work, or allowed me to cite them. This research was partly carried out at Newcastle University as a Visiting Fellow in the School of Historical Studies.

The University of Tokyo 3-8-1 Komaba, Meguro-ku

Tokyo 153-8902

JAPAN

Email: gdmiddleton@hotmail.com

\section{REFERENCES}

ASTOUR, M.C. 1968: Mesopotamian and Transtigridian place names in the Medinet Habu lists of Ramses III. Journal of the American Oriental Society 88, 733-52.

BachHuber, C. 2012: Sea Peoples. In Bagnall, R.S., Broderson, K., Champion, C.B., ERSkine, A. and HUEBNER, S.R. (eds.), Encyclopedia of Ancient History (Oxford).

BARAKO, T.J. 2000: The Philistine settlement as mercantile phenomenon? American Journal of Archaeology 104, 513-30.

BARAKo, T.J. 2003: Philistines upon the seas. Biblical Archaeology Review 29, 24-5.

BARNETT, R.D. 1975: The Sea Peoples. In EDWARDS, I.E., GADD, C.J., HAMMOND, N.G. and SOllberger, E., Cambridge Ancient History. Vol. 2 Part 2: History of the Middle East and the Aegean Region c.1380-1000 BC (Cambridge), 359-78.

BARRETT, C.E. 2009: The perceived value of Minoan and Minoanising pottery in Egypt. Journal of Mediterranean Archaeology 22, 211-34.

BEARD, M. 2008: Pompeii (London).

BEN-SHLOMO, D. 2010: Philistine Iconography: A Wealth of Style and Symbolism (Fribourg).

BEN-SHLOMO, D. 2011: Early Iron Age domestic material culture in Philistia and the Eastern Mediterranean koine. In YASUR-LANDAU, A., EBELING, J.R. and MAZOW, L.B. (eds.), Household Archaeology in Ancient Israel and Beyond (Leiden), 185-206.

BEN-SHLOMO, D. and PRESS, M.D. 2009: A reexamination of Aegean-style figurines in light of new evidence from Ashdod, Ashkelon, and Ekron. Bulletin of the American School of Oriental Studies 353, 39-74. BOMBARDIERI, L. and JASINK, A.M. 2010: Decorative repertoire and script signs: a complex 'origin' for the writing system in Cyprus? Kadmos 49, 133-59.

BUNIMOVITZ, S. and LEDERMAN, Z. 2011: Canaanite resistance: Philistines and Beth-Shemesh - a case study from Iron Age I. Bulletin of the American School of Oriental Studies 364, 37-51.

COLlARD, D. 2008: Function and Ethnicity: 'Bathtubs' from Late Bronze Age Cyprus (Uppsala).

CROSS, F.M. 1968: The Canaanite cuneiform tablet from Taanach. Bulletin of the American Society for Oriental Research 190, 41-6. 
CROSS, F.M. and FREEDMAN, D.N. 1971: An inscribed jar handle from Raddana. Bulletin of the American Society for Oriental Research 201, 19-22.

CROSS, F.M. and STAGER, L.E. 2006: Cypro-Minoan inscriptions found in Ashkelon. Israel Exploration Journal 56, 129-59.

DALGLISH, C. 2005: Urban myths: rethinking the archaeology of Scottish cities. Scottish Archaeology 27, $147-83$.

DAVIS, B. 2011: Cypro-Minoan in Philistia? Kubaba 2, 40-74.

Dickinson, о.т. 2006: The Aegean from Bronze Age to Iron Age: Continuity and Change between the Twelfth and Eighth Centuries BC (London).

DOthan, T. 1982: The Philistines and their Material Culture (Jerusalem).

DOTHAN, T. 1997: Tel Miqne/Ekron: an Iron Age I Philistine settlement in Canaan. In SILBERMAN, N.A. and SMALl, D. (eds.), The Archaeology of Israel: Constructing the Past, Interpreting the Present (Sheffield), 96-106.

Dothan, T. 2003: The Aegean and the Orient: cultic interactions. In DEVER, W.G. and Gitin, S. (eds.), Symbiosis, Symbolism, and the Power of the Past: Canaan, Ancient Israel, and their Neighbors from the Late Bronze Age through Roman Palaestina (Winona Lake), 189-213.

Dothan, T. and dothan, M. 1992: People of the Sea: The Search for the Philistines (New York).

DOTHAN, T. and ZUCKERMAN, A. 2004: A preliminary study of the Mycenaean IIIC:1 pottery assemblages from Tel Miqne-Ekron and Ashdod. Bulletin of the American School of Oriental Studies 333, 154.

DREWS, R. 1993: The End of the Bronze Age: Changes in Warfare and the Catastrophe ca. 1200 BC (Princeton).

DREWS, R. 1998: Canaanites and Philistines. Journal for the Study of the Old Testament 81, 39-61.

DREWS, R. 2000: Medinet Habu: oxcarts, ships and migration theories. Journal of Near Eastern Studies 59, $161-90$.

EMERY, K.F. 2002: The noble beast: status and differential access to animals in the Maya world. World Archaeology 34, 498-515.

ERIKSSON, G., LINDERHOLM, A., FORNANDER, E., KANSTRUP, M., SCHOULTZ, P., OLOFSSON, H. and LIDEN, K. 2008: Same island different diet: cultural evolution of food practice on Oland, Sweden, from the Mesolithic to the Roman period. Journal of Archaeological Science 27, 520-43.

FAGAN, B. 2004: The Long Summer: How Climate Changed Civilization (New York).

FANTALKIN, A. 2006: Identity in the making: Greeks in the eastern Mediterranean during the Iron Age. In VIlling, A. and SChlotzhauer, U. (eds.), Naukratis: Greek Diversity in Egypt. Studies on East Greek Pottery and Exchange in the Eastern Mediterranean (London), 199-208.

FAUST, A. and LEV-TOV, J. 2011: The constitution of Philistine identity: ethnic dynamics in twelfth to tenth century Philistia. Oxford Journal of Archaeology 30, 13-31.

FRENCH, E. 1971: The development of Mycenaean terracotta figurines. Annual of the British School at Athens 66, 101-87.

FRITZ, V. 1987: Conquest or settlement? The Early Iron Age in Palestine. Biblical Archaeologist 50, 84-100.

GOREN, Y., BUNIMOVITZ, S., FINKELSTEIN, I. and NA'AMAN, N. 2003: The location of Alashiya: new evidence from petrographic investigation of Alashiyan tablets from El-Amarna and Ugarit. American Journal of Archaeology 107, 233-55.

HALSTEAD, P. 2003: Texts and bones: contrasting Linear B and zooarchaeological evidence for animal exploitation in Mycenaean southern Greece. In KOTJABOPOULOU, E., HAMILAKIS, Y., HALSTEAD, P., GAMBle, C. and ElEFANTI, P. (eds.), Zooarchaeology in Greece: Recent Advances (Athens), 25761.

HAMILAKIS, Y. and KONSOLAKI, E. 2004: Pigs for the gods: burnt animal sacrifices as embodied rituals at a Mycenaean sanctuary. Oxford Journal of Archaeology 23, 135-51.

HARL, K.W. 2011: The Greeks in Anatolia: from the migrations to Alexander the Great. In STEADMAN, S.R. and MCMAHON, G. (eds.), The Oxford Handbook of Ancient Anatolia (Oxford), 752-74.

HIRSCHFELD, N. 2008: How and why potmarks matter. Near Eastern Archaeology 71, 120-9.

HIRSCHFELd, N. 2010: Cypro-Minoan. In Cline, E.H. (ed.), The Oxford Handbook of the Late Bronze Age Aegean (Oxford), 373-84.

HOOD, S. 1978: The Arts in Prehistoric Greece (New Haven). 
HOROWITZ, W., OSHIMA, T. and SANDERS, S. 2002: A bibliographical list of cuneiform inscriptions from Canaan, Palestine/Philistia, and the Land of Israel. Journal of the American Oriental Society 122, $753-66$.

IEZZI, C. 2009: Regional differences in the health status of the Mycenaean women of East Lokris. In SCHEPARTZ, L.A., FOX, S.C. and Bourbou, C. (eds.), New Directions in the Skeletal Biology of Greece (Princeton), 175-92.

ISAAKIDOU, V., HALSTEAD, P., DAVIS, J. and STOCKER, S. 2002: Burnt animal sacrifice at the Mycenaean 'Palace of Nestor', Pylos. Antiquity 76, 86-92.

JANEWAY, B. 2006-7: The nature and extent of Aegean contact at Tell Ta' yinat and vicinity in the Early Iron Age: evidence of the Sea Peoples? Scripta Mediterranea 27-8, 123-46.

JANEWAY, B. 2011: Mycenaean bowls at 12th/11th century BC Tell Tayinat (Amuq Valley). In Karageorghis, v. and Kouka, o. (eds.), On Cooking Pots, Drinking Cups, Loomweights and Ethnicity in Bronze Age Cyprus and Neighbouring Regions (Nicosia), 167-85.

JONES, M., HUNT, H., LIGHTFOOT, E., LISTER, D., LIU, X. and MOTUZAITE-MATUZEVICIUTE, G. 2011: Food globalization in prehistory. World Archaeology 43, 665-75.

JONES, N. 2010: The Normans. Britain 78, 80-7.

KANIEWSKI, D., VAN CAMPO, E., VAN LERBERGHE, K., BOIY, T., VANSTEENHUYSE, K., JANS, G., NYS, K., WEISS, H., Morhange, C., OtTo, T. and BRetschneIDER, J. 2011: The Sea Peoples, from cuneiform tablets to carbon dating. PLoS One 6(6), e20232, 1-7.

KARAGEORGHIS, V. 1998a: Mycenaean 'acropoleis' in the Aegean and Cyprus: some comparisons. In CLINE, E.H. and HARris-Cline, D. (eds.), The Aegean and the Orient in the Second Millennium BC (Liège, Aegaeum 18), 127-36.

KARAGEORGHIS, v. 1998b: Hearths and bathtubs in Cyprus: a 'Sea Peoples' innovation? In GITIN, S., MAZAR, A. and STERn, E. (eds.), Mediterranean Peoples in Transition: Thirteenth to Early Tenth Centuries $B C E$ (Jerusalem), 276-82.

KARAgeorghis, v. 2000: Cultural innovations in Cyprus relating to the Sea Peoples. In OREN, E.D. (ed.), The Sea Peoples and their World: A Reassessment (Philadelphia), 255-79.

KARAgeorghis, v. 2001: Patterns of fortified settlements in the Aegean and Cyprus c.1200 BC. In KARAgeOrghis, v. and MORRIS, C.E. (eds.), Defensive Settlements of the Aegean and the Eastern Mediterranean after c. 1200 BC (Nicosia), 1-12.

KILIAN, K. 1988a. Mycenaeans up to date, trends and changes in recent research. In FRENCH, E.B. and WARDLE, K.A. (eds.), Problems in Greek Prehistory (Bristol), 115-52.

KILIAN, K. 1988b. The emergence of wanax ideology in the Mycenaean palaces. Oxford Journal of Archaeology 7(3), 291-302.

KILLEBREW, A.E. 1998: Aegean and Aegean-style material culture in Canaan during the 14th-12th centuries BC: trade, colonization, diffusion or migration? In CLINE, E.H. and HARRIS-CLINE, D. (eds.), The Aegean and the Orient in the Second Millennium BC (Liège, Aegaeum 18), 159-71.

KILLEBrew, A.E. 2005: Biblical Peoples and Ethnicity: An Archaeological Study of Egyptians, Canaanites, Philistines, and Early Israel, c. 1300-1100 BCE (Atlanta).

KILLEBREW, A.E. 2006-7: The Philistines in context: the transmission and appropriation of Mycenaeanstyle culture in the east Aegean, southeastern coast of Anatolia, and the Levant. Scripta Mediterranea 27-8, 244-66.

KLEINMAN, A. and BENSON, P. 2006: Anthropology in the clinic: the problem of cultural competency and how to fix it. PLoS Medicine 3, e294.

KNAPP, A.B. 2008: Prehistoric and Protohistoric Cyprus: Identity, Insularity, and Connectivity (Oxford).

KNAPP, A.B. 2009: Migration, hybridisation and collapse: Bronze Age Cyprus and the Eastern Mediterranean. Scienze dell'anchita. Storia Archeologia Antropologia 15, 219-39.

KNAPP, A.B. 2013: The Archaeology of Cyprus from Earliest Prehistory through the Bronze Age (Cambridge).

KUHRT, A. 1995. The Ancient Near East (London).

LAVIOLETTE, A. 2008: Swahili cosmopolitanism in Africa and the Indian Ocean world, AD 600-1500. Archaeologies: Journal of the World Archaeological Congress 4, 24-49.

LIPOVITCH, D.R. 2006-7: Modeling a Mycenaean menu: can Aegean populations be defined in Near Eastern contexts based on their diet? Scripta Mediterranea 27-8, 147-59. 
LIS, B. 2006: The role of cooking pottery and cooked food in the Palace of Nestor at Pylos. Archeologia 57, $7-24$.

LONGO, U.G., SPIEZIA, F., MAFFuli, N. and DENARO, v. 2008: The best athletes in ancient Rome were vegetarian! Journal of Sports Science and Medicine 7, 565.

MAC SWEENEY, N. 2009: Beyond ethnicity: the overlooked diversity of group identities. Journal of Mediterranean Archaeology 22, 101-26.

MAC SWEENEY, N. 2011: Strange and estranged: perceiving cultural contacts in Late Bronze Age-Early Iron Age Anatolia. In DuistermaAt, K. and Regulski, I. (eds.), Intercultural Contacts in the Ancient Mediterranean (Leuven), 67-77.

MARAN, J. 2001: Political and religious aspects of architectural change on the Upper Citadel of Tiryns: the case of Building T. In LAFFINEUR, R. and HÄGG, R. (eds.), POTNIA. Deities and Religion in the Aegean Bronze Age (Liège, Aegaeum 22), 113-22.

marshall, M. 2012: Collapse: when nature destroys civilizations. New Scientist 4th August, 32-6.

MAZAR, A. 2008: From 1200 to 850 BCE: remarks on some selected archaeological issues. In GRABBE, L.L. (ed.), Israel in Transition: From Late Bronze II to Iron IIa (c. 1250-850 BCE). Vol. 1: The Archaeology (New York), 86-120.

MAzOW, L.B. 2006-7: The industrious Sea Peoples: the evidence of Aegean-style textile production in Cyprus and the southern Levant. Scripta Mediterranea 27-8, 291-321.

middleton, G.D. 2010: The Collapse of Palatial Society in Late Bronze Age Greece and the Postpalatial Period (Oxford).

MOUNTJOY, P.A. 1993: Mycenaean Pottery: An Introduction (Oxford).

MOUNTJOY, P.A. 2010: A note on the mixed origins of some Philistine pottery. Bulletin of the American Society for Oriental Studies 359, 1-12.

MOUNTJOY, P.A. and PONTING, M.J. 2000: The Minoan thalassocracy reconsidered: provenance studies of LH II A/LM I B pottery from Phylakopi, Ay. Irini and Athens. Annual of the British School at Athens 95, 141-84.

MUHLY, J.D. 1984: The role of the Sea Peoples in Cyprus during the LCIII period. In KARAGEORGHIS, V. and MuHLY, J.D. (eds.), Cyprus at the Close of the Late Bronze Age (Nicosia), 39-55.

NORTON, M. 2006: Tasting empire: chocolate and the European internalization of Mesoamerican aesthetics. American Historical Review 111(3), 660-91.

NUNN, N. and QIAN, N. 2010: The Columbian exchange: a history of disease, food, and ideas. The Journal of Economic Perspectives 24, 163-88.

palaima, T.G. 2004: Sacrificial feasting in the Linear B documents. Hesperia 73, 217-46.

PETROUTSA, E. and MANOLIS, S.K. 2010: Reconstructing Late Bronze Age diet in mainland Greece using stable isotope analysis. Journal of Archaeological Science 37, 614-20.

POPHAM, м. 1994: The collapse of Aegean civilization. In CunLIFFE, B. (ed.), The Oxford Illustrated Prehistory of Europe (Oxford), 277-303.

Rosenblum, J.D. 2010: 'Why do you refuse to eat pork?' Jews, food, and identity in Roman Palestine. The Jewish Quarterly Review 100, 95-110.

RUSSELl, A. 2010: Foreign materials, islander mobility, and elite identity in Late Bronze Age Sardinia. In VAN DOMMElEn, P. and KNAPP, A.B. (eds.), Material Connections in the Ancient Mediterranean: Mobility, Materiality, and Identity (London), 106-26.

RUTTER, J.B. 2007: How different is LH IIIC Middle at Mitrou? An initial comparison with Kalapodi, Kynos, and Lefkandi. In DEger-Jalkotzy, s. and Zavadil, M. (eds.), LH IIIC Chronology and Synchronisms II: LH IIIC Middle (Vienna), 287-300.

SAgOnA, A.G. and ZIMANSKy, P. 2009: Ancient Turkey (Oxford).

SANDARS, N.K. 1978: The Sea Peoples: Warriors of the Ancient Mediterranean, 1250-1150 BC (London).

SHERRATT, E.S. 1998: 'Sea Peoples' and the economic structure of the late second millennium in the Eastern Mediterranean. In GITIN, S., MAZAR, A. and STERN, E. (eds.), Mediterranean Peoples in Transition: Thirteenth to Early Tenth Centuries BCE (Jerusalem), 292-313.

SHERRATT, E.S. 2001: Potemkin palaces and route-based economies. In VOUTSAKI, S. and KILLEN, J. (eds.), Economy and Politics in the Mycenaean Palace States (Cambridge), 214-38.

SHERRATT, E.S. 2003: The Mediterranean economy: 'globalization' at the end of the second millennium BCE. In DEVER, w.G. and Gitin, s. (eds.), Symbiosis, Symbolism, and the Power of the Past: Canaan, 
Ancient Israel, and their Neighbors from the Late Bronze Age through Roman Palaestina (Winona Lake), 37-62.

SHERRATT, E.S. 2004: Feasting in Homeric epic. Hesperia 73, 301-37.

SHERRATT, E.S. 2005: 'Ethnicities', 'ethnonyms', and archaeological labels. Whose ideologies and whose identities? In ClARKE, J. (ed.), Archaeological Perspectives on the Transition and Transformation of Culture in the Eastern Mediterranean (Oxford), 25-38.

SHERRATT, E.S. 2006: The chronology of the Philistine monochrome pottery - an outsider's view. In MAEIR, A.M. and DE MIROSCHEDJI, P. (eds.), 'I will speak the riddles of ancient times': Archaeological and Historical Studies in Honor of Amihai Mazar on the Occasion of his Sixtieth Birthday (Winona Lake), $361-74$.

SHERRATT, E.S. and HAMILAKIS, Y. 2012: Feasting and the consuming body in Bronze Age Crete and Early Iron Age Cyprus. In CADOGAN, G., IAKOvou, M., KOPAKA, K. and WHitley, J. (eds.), Parallel Lives: Ancient Island Societies in Crete and Cyprus (London).

Silberman, N.A. 1998: The Sea Peoples, the Victorians, and us: modern social ideology and changing archaeological interpretations of the Late Bronze Age collapse. In GITIN, S., MAZAR, A. and STERN, E. (eds.), Mediterranean Peoples in Transition: Thirteenth to Early Tenth Centuries BCE (Jerusalem), 268-75.

StAger, L.E. 1995: The impact of the Sea Peoples in Canaan (1185-1050 BCE). In LEVy, T.E. (ed.), The Archaeology of Society in the Holy Land (London), 332-48.

STEeL, L. 2004a: A goodly feast ... A cup of mellow wine: feasting in Bronze Age Cyprus. Hesperia 73, 281-300.

STEEL, L. 2004b: Cyprus Before History: From the Earliest Settlers to the End of the Bronze Age (London). STOCKER, S.R. and DAVIS, J.L. 2004: Animal sacrifice, archives, and feasting at the Palace of Nestor. Hesperia 73, 179-95.

STOCKHAMMER, P. 2011: Household archaeology in LHIIIC Tiryns. In YASUR-LANDAU, A., EBELING, J.R. and MAZOW, L.B. (eds.), Household Archaeology in Ancient Israel and Beyond (Leiden), 207-36.

STONE, B.J. 1995: The Philistines and acculturation: culture change and ethnic continuity in the Iron Age. Bulletin of the American School of Oriental Studies 298, 7-32.

THOMPSON, H.M. 2003: Significance and fate of the native English landholders of 1086. English Historical Review 118, 303-33.

TOURNAVITOU, I. 1992: Practical use and social function: a neglected aspect of Mycenaean pottery. Annual of the British School at Athens 87, 181-210.

TWISs, K. 2012: The archaeology of food and social diversity. Journal of Archaeological Research 20, 357-95.

UNIVERSITY OF MINNESOTA n.d.: Ekron: the successive remains of Field IV, http://cnes.cla.umn.edu/ courses/archaeology/Ekron/EkronFieldIVFrameset.html

VAN WIJNGAARDEN, G.J. 1999: An archaeological approach to the concept of value. Mycenaean pottery at Ugarit (Syria). Archaeological Dialogues 6, 2-23.

VAN WIJNGAARDEN, G.J. 2002: Use and Appreciation of Mycenaean Pottery in the Levant, Cyprus and Italy (ca 1600-1200 BC) (Amsterdam).

VAN WIJNGAARDEN, G.J. 2008: The relevance of authenticity: Mycenaean-type pottery in the Mediterranean. In BIEHL, P.F. and RASSAMAKIN, Y.YA. (eds.), Import and Imitation in Archaeology (Langenweißbach), $125-45$.

VANSCHOONwinkel, J. 1999: Between the Aegean and the Levant: the Philistines. In TSETSKHLADZE, G.R. (ed.), Ancient Greeks West and East (Leiden), 85-108.

Verstraete, J. 2012: Reinterpreting the Aegean and Aegean-like pottery in the Amuq Valley (Turkey): from Late Bronze Age object to Early Iron Age symbol. Paper presented at the 113th Annual Meeting of the Archaeological Institute of America, Philadelphia, PA January 6, 2012.

waChSMAnn, S. 1998: Seagoing Ships and Seamanship in the Bronze Age Levant (London).

WACHSMANN, s. 2003: Response: A complex migration: did the Philistines get to Canaan by land or by sea? Biblical Archaeology Review 29, 22.

WILKInson, T. 2010: The Rise and Fall of Ancient Egypt (London).

WILSON, J.A. 1956: The royal myth in ancient Egypt. Proceedings of the American Philosophical Society $100,439-42$.

WRIGHT, J.C. 2004: A survey of evidence for feasting in Mycenaean society. Hesperia 73, 133-78. 
YASUR-LANDAU, A. 2001: The mother(s) of all Philistines? Aegean enthroned deities of the 12th-11th century Philistia. In LAfFInEur, R. and HÄGG, R. (eds.), POTNIA. Deities and Religion in the Aegean Bronze Age (Liège, Aegaeum 22), 329-43.

Yasur-landaU, A. 2003: How did the Philistines get to Canaan? Two: by land. Biblical Archaeology Review 29, 34-9, 66-7.

YASUR-LANDAU, A. 2006: A LH IIIC stirrup jar from Area K. In FINKELSTEIN, I., USSISHKIN, D. and HALPERN, B. (eds.), Meggido IV: The 1998-2002 Seasons (Tel Aviv), 299-302.

Yasur-Landau, A. 2010: The Philistines and Aegean Migration at the End of the Late Bronze Age (Cambridge).

ZUCKERMAN, S. 2007: 'Slaying oxen and killing sheep, eating flesh and drinking wine . . '? feasting in Late Bronze Age Hazor. Palestine Exploration Quarterly 139, 186-204. 